\title{
The Sepulchral Symbolism and Workshop Comparison of the Raptus of the Sabines Sarcophagus and the Metilia Acte Sarcophagus
}

\author{
Fred A. White ${ }^{1,2}$ \\ ${ }^{1}$ Curator-in-Charge of the Archaeological Collections, Florida Archaeological Survey, Gainesville, FL, USA \\ ${ }^{2}$ Advisory Council and Collections, Appleton Museum of Art, College of Central Florida, Ocala, FL, USA
}

\author{
Email address: \\ nationalarchaeology@mail.com
}

\section{To cite this article:}

Fred A. White. The Sepulchral Symbolism and Workshop Comparison of the Raptus of the Sabines Sarcophagus and the Metilia Acte Sarcophagus. International Journal of Archaeology. Vol. 3, No. 1, 2015, pp. 1-7. doi: 10.11648/j.ija.20150301.11

\begin{abstract}
The sarcophagus illustrating the story of the Sabine Women at the Cornell Fine Arts Museum is believed to have been obtained in Rome between 1899 and 1904 by Alfred Emerson, Professor and Chair of Classical Archaeology at Cornell University, Fellow at John Hopkins University and the Curator of Antiquities at the Art Institute of Chicago. The Metilia Acte sarcophagus illustrating the story of Alkesstis at the Vatican in the Museo Chiaramonti was discovered in Ostia in 1826 by the architect Pietro Hall and Felice Cartoni. The Sabine sarcophagus dates to the second century A.D. and the Alkēstis sarcophagus dates by the inscription to between the years 160-170 A.D. The Sabine story is the Raptus of the Sabine Women while the Alkēstis story is according to Euripides' drama, Alkēstis. Metilia Acte was the priestess of the Magna Mater deorum Idaea cult that worshipped the goddess Cybele. The Alkēstis themed sarcophagus also held Metilia Acte's husband Caius Junius Euhodus, the magister of the fabri tignarii carpenter guild. The qualities of both the reliefs accurately represent the Roman artistic style of the second century and were executed by the same guild or similar workshops in Rome during the second century Nerva-Antonine dynasty.
\end{abstract}

Keywords: Sarcophagus, Sabine, Roman, Metilia Acte, Marble, Quarry, Archaeometry, Provenance

\section{Introduction}

A marble provenance investigation using four different techniques: electron paramagnetic resonance (EPR) spectroscopy, stable isotope analysis, maximum grain size measurement, and in-situ examination confirmed the Sabine sarcophagus was quarried from the ancient Luna site and archaeometry studies of the sculptures and funerary monuments recovered from the Ostia archaeological site demonstrate they are also from the second century A.D. Luna quarry [1-2]. There were a few examples of sculptures imported from the Greek sites of Parian and Thasian also found at Ostia the harbor city of ancient Rome, but the marbles are patently different from the ones quarried in Luna and are easy to distinguish [3-4]. Both of the highly decorative bas-reliefs illustrating the mythology of the Sabines and Alkesstis are remarkably similar in addition to being made from marble quarried from the same ancient site. In-depth style comparison of the Metropolitan Roman sarcophagi enables attribution - to be closely narrowed between the reigns of Antoninus Pius and through to Marcus Aurelius [5].

\section{Discussion}

The front of the Sabine sarcophagus "Figure 1" is decorated with sixteen human figures carved in high relief. In the left background there is an Ionic order temple, historically the one dedicated to Quirinus, a Sabine cult god of war, located on the Collis Quirinalis. The front of the Alkēstis sarcophagus "Figure 2" is illustrated with seventeen adult figures and as well the left scene illustrates Thanatos approaching through the arched temple like entrance of King Admetus' palace in Pherae. The mature Thanatos is depicted nude with a chlamys drape holding a spear. The placement and scale of the temple and palace temple arch on each of the sarcophagi are nearly identical. The architectural elements of temples incorporated in some sarcophagi designs have been thought to somehow heroize the deceased. Examining the corpus of preserved Roman sarcophagi, stylistic features like 
these appear in the range of mythological sarcophagi, but their relationship to the entire length of the sarcophagus and the scale to the human figures demonstrate they were executed by a workshop or workshops that followed the same collectively learned measurements and design.

To carve the reliefs a good deal of planning was needed to accurately calculate the proportions of the figures so that the way they were posed fit properly into the relative overall scale. The complete design, the numbers of figures and the background structures would often be measured on the block before cutting the composition from the marble; however the artists had interpretational flexibility within that geometric space. There are remarkable similarities in overall length, height, wall thickness, and the scale of the figures compared to the overall height. Even the figures' poses, distances, actions and the side and profile views are of the same design school. One would expect similarities because both sarcophagi could have been produced first in blank form at the same rough cutting workshop and then carried to Rome for the final relief carving, but the reliefs themselves demonstrate the work of a closely net group, with masters and apprentices that used the same technical processes.

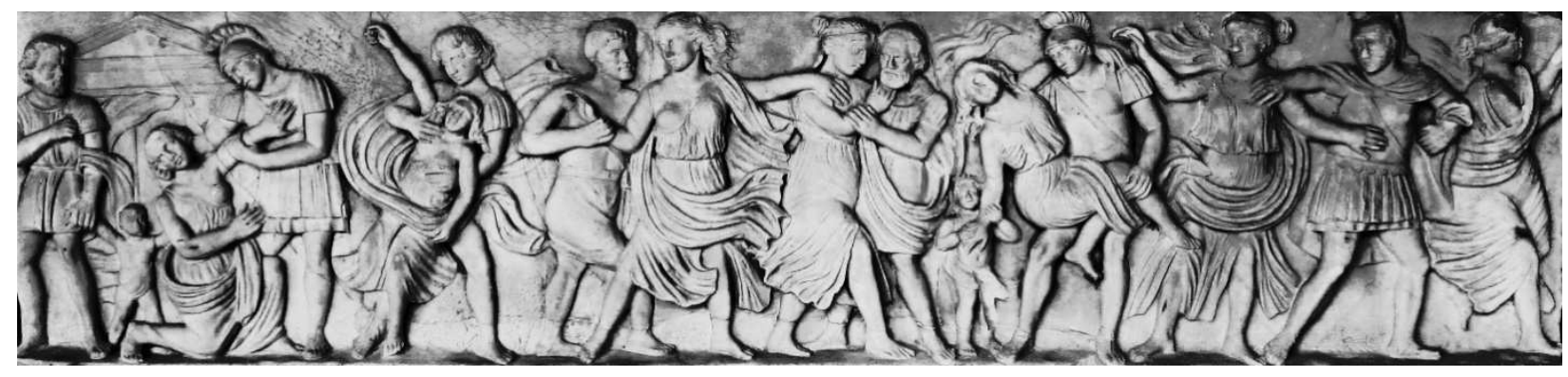

Figure 1. The Raptus of the Sabines sarcophagus, circa. $2^{\text {nd }}$ century A.D.

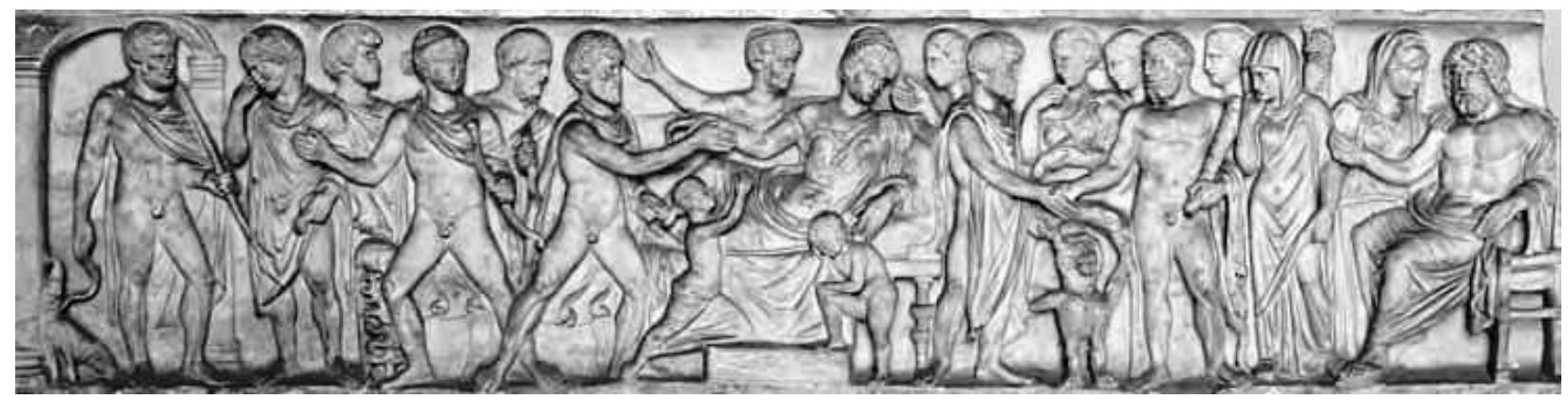

Figure 2. The Metilia Acte sarcophagus, Vatican Museo Chiaromonti. 160-170 A.D.

Both of these sarcophagi fit the most common shape for Metropolitan Roman sarcophagi which was the low sided rectangular box style with three finished sides. It was unusual for the back side to be decorated as Roman sarcophagi were normally placed in niches or against a wall in mausolea. One of the Twelve Tables laws of 451 B.C. prevented burials within Rome's city boundary as this pomerium was considered sacred and thus tombs and cemeteries line the roads leading out of the city. Beginning around 110 A.D. Rome was the primary production center for sarcophagi of the western empire, but there exists too much diversity in other extant examples of Roman mythological sarcophagi however to suggest the idea of a workshop monopoly in Rome. In Asia Minor however there is evidence that the Prokonessos quarries produced sarcophagi with decorative elements already complete or had areas on them blocked out, unfinished for the addition of personal details.

The Sabine relief imagery evolved from the legendary history of Rome, in which the men of the area acquired wives from the neighboring Sabine families. This iconography is one of the traditional heroic themes found in relief carvings, as the Sabine women are revered as the mothers of the first
Romans. Roman culture had a long history of decorating reliefs with what are categorized as heroic rape scenes [2]. The Roman necropolis in Sempeter Slovenia contains the beautiful tomb of the Quintus Ennius Liberalis family which based on visual characteristics was built in the Antonine dynasty. It is illustrated with two mythological reliefs. The front panel depicts the Rape of Phoenician Europa by Zeus, and the right panel depicts the Rape of Ganymede [6-7]. Throughout the remains of the Roman Empire other sepulchral reliefs have been discovered with subjects that include the rapes of Daphne, Io, Proserpina, Leda and the daughters of Leucippus.

Around the end of the fourth century A.D. popular narratives like the abduction of the Sabines began to quickly vanish from Roman art and culture. This rapid decline appears to be related to the increased power of the Christian church and its extreme disdain for these types of pagan mythology [8]. These stories portraying the heroic rape iconography are extremely complex and represent a violence that usually begins with the abduction of the women. In ancient Rome the term raptus (rape) was defined as a crime of theft, essentially to carry away by force [9]. The highly symbolic sepulchral imagery in these myths offered many 
interpretive possibilities, from the hope of a pleasurable afterlife, virtue, bravery and the ultimate victory over death.

The predominant scene on the Metilia Acte - Alkēstis sarcophagus displays the death of Alkēstis. The queen is on her bed looking away, as towards the afterlife and Admetus at her side is holding the hand of his dying wife. There are many spectators, her son and daughter morn while a maid servant attends the dying queen. The action is based around Euripides' account of the drama, where Hercules leads Alkēstis back to the living and away from the Etruscan inspired shadowy underworld of Hades. The scenes on the Alkēstis sarcophagus present interpretations of old myths according to the Neopythagorean symbolism of life beyond the other world. The motifs are copied directly from Euripides [5] [10].

On both sarcophagi the men wear the traditional ephaptis or chlamys cloaks. Evolving from the Greek, this simple drape is often the only clothing depicted on soldiers and hunters. The Sabine iconography displays the Roman legionary uniforms which demonstrate accurately the period skirt with leather tassets, tunic, sagum drape and the one shoulder baldric belts. Imperial helmets of the $1^{\text {st }}-2^{\text {nd }}$ century were designed to attach ceremonial crests, thus the portrayal here of helmets with horsehair crests fits within the context of the narrative in which the Sabine women were abducted during the Festival of Neptunus Equester. Several men on the Alkēstis sarcophagus appear to be portrayed as hunters or returning from the hunt [11-12].

On both sarcophagi the women are wearing wool chiton and himation drapes common in circa $1^{\text {st }}-2^{\text {nd }}$ century A.D. period sculpture. The particular hairstyles of the women and men were popularized during the Julio-Claudian Period, circa $1^{\text {st }}$ century A.D. and continued throughout the Antonine Period. There is a resemblance of Marcus Aurelius and Lucius Verus among the style of the men's heads with their coiffures and beards on both sarcophagi. The majority of Roman men attempted to stay clean shaven until around the death of Trajan in 117 A.D. and then things rapidly changed when Hadrian came to rule. He wore a beard in the Greek style he admired and soon nearly all Roman men were wearing beards. Similar hair and tunics are found on the $2^{\text {nd }}$ century A.D. funerary urn of Julia Eleutherides that depicts the memorial banquet.

On the Sabine sarcophagus you can still see the bedding for and traces of the ancient Roman iron clamps that once held the lid in place as a precaution against dislodging the interred. Cuttings such as these are found on many other preserved second and third century A.D. Roman sarcophagi and excellent teaching examples of these can be seen on the Badminton sarcophagus in the Metropolitan Museum in New York, a sarcophagus from Roman Britain in the British Museum, London and an iron clamp remains intact on the end of the Dionysiac sarcophagus in the Museum of Fine Arts, Boston [13-16].

From the blocked drain holes in one end of the Sabine sarcophagus we know it was also reused at some stage of its history as a water basin, a common fate of Roman sarcophagi.
The mid-second century A.D. Luna marble sarcophagus in the Carlos Museum at Emory University in Atlanta exhibits a similar drain hole in one end, as well the cuttings for the iron lid clamps.

Scientific studies confirm the Sabine sarcophagus and sepulchral sculpture from Ostia both came from the ancient Carrara quarries that were located in the Apuan Alps, part of the northern Apennines range in Italy [2-3]. Only sporadic quarrying existed before the $1^{\text {st }}$ century B.C. but during the $1^{\text {st }}$ and $2^{\text {nd }}$ century A.D. this marble called Luna in ancient times because of the town of Luna's proximity to the Carrara Mountains, became a supply source for building in Rome and the included Ostia area. The use of the ancient (Luna) Carrara quarry peaked during the time of Trajan 98 to 117 A.D. In the $2^{\text {nd }}$ century Carrara was quickly replaced by other marbles originating from the Eastern Mediterranean, particularly the white Proconnessos type [17]. By the end of the $2^{\text {nd }}$ century eastern white marbles had become the supply source for building and decorative needs like sculpture and funerary reliefs. In the early third century Proconnesian marble was the preferred stone chosen by Romans for their sarcophagi. These facts provide ease of dating Roman marble artifacts based on the ancient quarry of provenance [18-22].

After the marble was quarried in the Etruria region it was carried to Rome where it was worked. The marble sample from the Sabine sarcophagus was scientifically analyzed against 524 other samples including the six ancient Roman quarry sites of Carrara (Luna), Pentelicon, Hymettos, Docimium (Iscehisar), Docimium (Altintaş), and the three groups at Göktepe. It was confirmed that the isotopic, EPR evidence and the color value percent of the Sabine sample of ancient Carrara (Luna) Marble also has a high match to other database samples including marble from The Pantheon, Rome completed 126 A.D., The Sarcophagus with Three Pairs of Captive Amazons, London 180-220 A.D., Trajan's Column, Rome completed 113 A.D., and The Sarcophagus of the Triumph of Bacchus, Lyon c. 200 A.D. [23-27]. This qualitative conclusion is fully supported by the quantitative results and thus the dating of Sabine sarcophagus circa $2^{\text {nd }}$ century A.D. is extremely accurate. The fact that the Alkēstis sarcophagus is the same marble type and has an accurately established date for the inscription on the front of the sarcophagus stating that the still living husband dedicated this monument to the deceased spouse with a date between 160 and 170 A.D. adds evidence to the attribution between the reigns of Antoninus Pius and through to Marcus Aurelius [5]. The husband making the dedication was Caius Junius Euhodus, who at that time was the magister of the fabri tignarii carpenter guild and his deceased wife was the priestess of the Magna Mater deorum Idaea cult, Metilia Acte. The cult had beliefs centered on worshipping the goddess Cybele.

Though the second century A.D. marked an ascent of Roman sarcophagi, which peaked artistically in the third century, metropolitan Rome workshop examples from the second century exceeded those produced in Asia Minor. 
Though dated to the second century, the quality of the relief carvings on these two surviving sarcophagi are not considered to be the best examples offered from artisans of the period or in the style of high polished bas-relief. An excellent $2^{\text {nd }}$ period A.D. example of high polish is the relief in the Forum Romanum of Hadrian giving the funeral oration for his wife Sabina. The conservative level of quality for the two sarcophagi is significant in that it confirms the date range as most surviving personal reliefs contained similar elements as state imperial reliefs however they were not as highly refined as state examples. Art historians correlate this with the Antonine Plague falling within the same date range as these sarcophagi. The Antonine Plague also known as the Plague of Galen was a twenty year cycle of pandemics involving small pox and measles which killed five million people and decimated the Roman army [2]. The death rate reached 2000 per day in Rome and even claimed the Roman Emperor Lucius Verus in 169 A.D. Personal sculpture quality suffered during this time as the quality of state work was consistent [10].

There are numerous references that document sarcophagi sculpted with scenes from the Rape of the Sabines. The Director of the British School at Rome Dr. Thomas Ashby, D.Litt, F.B.A., F.S.A., published an account involving the excavation of a Raptus of the Sabines sarcophagus. Dr. Ashby was the prestigious Craven Fellow in the University of Oxford, the Corresponding Member of the German Imperial Archaeological Institute, a Fellow of the British Academy and a Fellow of the Society of Antiquaries of London. His work refers to a Roman Metropolitan sarcophagus with the Sabine iconography belonging to an age before Emperor Alexander Severus, because of the construction materials of the tomb. Stone stamps and the brickwork of the tomb passage were from the age of Emperor Hadrian and water pipes identified date circa 166 A.D. [28]. Another historic reference is the inscription published by Forcella, Iscrizioni di Roma, i. no. 91, from Valesio, The Iscrizioni e Memorie d Antichita is from the May $4^{\text {th }} 1582$ Communal Council of Rome discussing a sarcophagus carved with the Raptus of the Sabines iconography. In the late sixteenth century the famous Italian sculptor and historian Flaminio Vacca in his di varie antichità trovate in diversi luogia della Città di Roma, records the discovery of a "sarcophagus sculptured with the rape of the Sabines." Flaminio Vacca recorded in intense detail the discoveries of Roman sculpture during the sixteenth century construction projects of Pope Sixtus V. [29]. Vacca's clear descriptions of Roman antiquities and sculpture are considered an accurate primary source. Pope Sixtus V was responsible for the destruction of many antiquities during his urbanization plans and if it were not for Flaminio Vacca, their existence would have never been known. Additional references include one by Adolf Michaelis, the German classical scholar and professor of art history at the University of Strasbourg, about a Sabine sarcophagus [30] and by Giovanni Francesco Cecconi in Roma Sacra e Moderna [31]. There is also testimony of a Sabine sarcophagus in Roma nobilitata nelle sue fabbriche by Giovanni Battista Gaddi [28] [32-33]. Richly carved sarcophagi are rare and it is fortunate that the Roman Metropolitan sarcophagus with the Rape of the Sabine Women mythology has been conserved and scientifically dated to the second century Nerva-Antonine dynasty [2].

\section{Conclusions}

The aim of our discussion was to contribute some additional observations and ascertainments of these two sarcophagi and include the comparison of the construction material and the relief styles.

Both mythological sarcophagi were created under the influence of Neo-Atticism and Antonine baroque styles and both sarcophagi are reflections of the great Roman artistry born of the eastern Mediterranean [5-7] [34-35]. The $2^{\text {nd }}$ century A.D. Rape of the Sabine Women sarcophagus detail "Figure 3" contains parallel elements of stylistic classicism found in the friezes of the Basilica Aemilia "Figure $4 \& 5$ ". These high quality state reliefs sculpted in the first century A.D. were located in the Forum Romanum and were observable to artisans of the period and would have been used as study references.

Both sarcophagi are accurately dated to the same second century Nerva-Antonine dynasty and appear to have been worked in primary blank form using a similar template [36-41]. The final relief forms illustrated on both sarcophagi demonstrate they were executed by a workshop or workshops that followed the same collectively learned measurements and design. The stylistic layouts on both marble sarcophagi also reveal detailed planning was needed to accurately calculate the proportions of the figures to fit properly into the relative overall scale.

Investigations of the stylistic components from the corpus of sarcophagi constructed in the city of Rome obviously demonstrate too great a diversity for a single workshop; however these two fine examples represent a culmination of the expression for sepulchral symbolism carved by a guild or workshops with similar experience. 


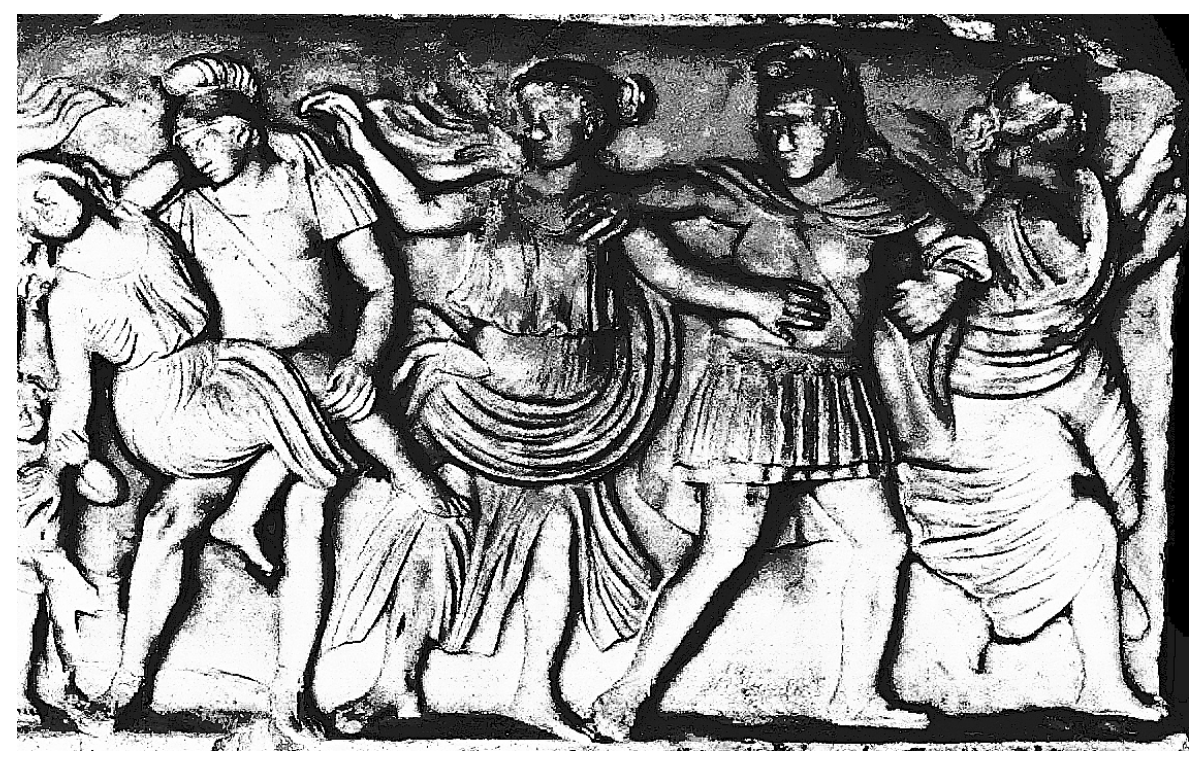

Figure 3. The Raptus of the Sabines sarcophagus, right front detail, circa. $2^{\text {nd }}$ century A.D.

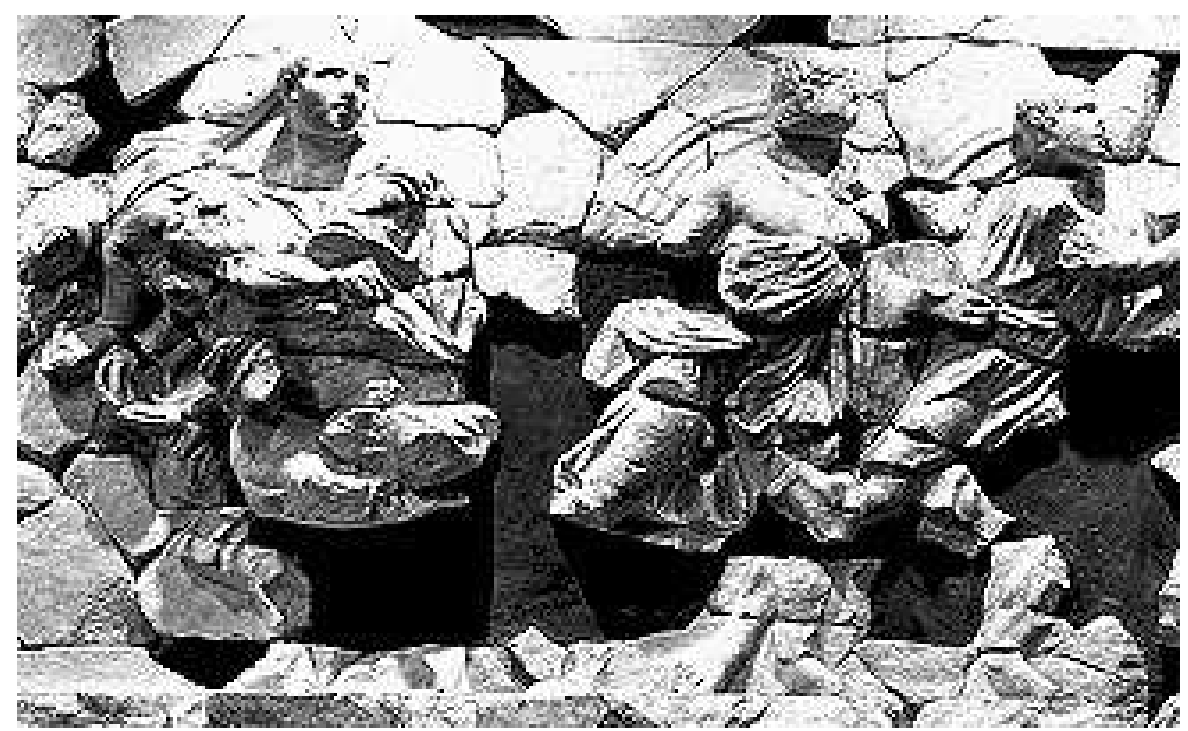

Figure 4. The Raptus of the Sabines Women, Basilica Aemilia, frieze detail, 1st century A.D.

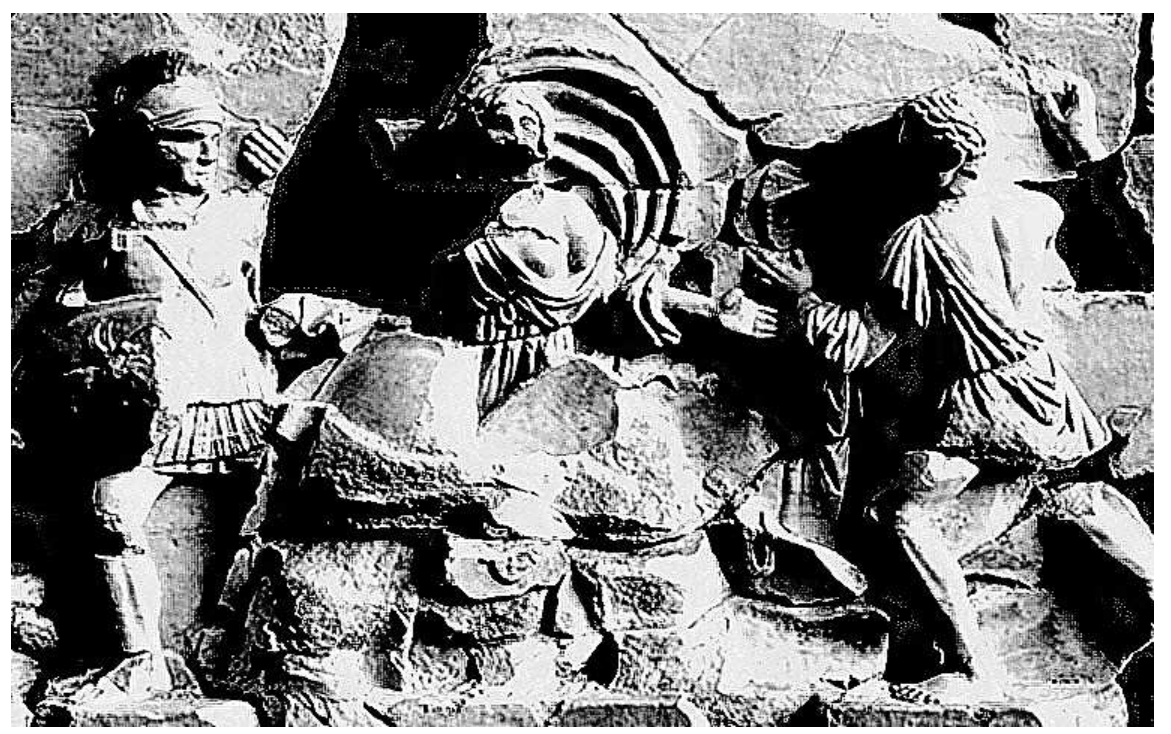

Figure 5. Sabine soldiers attacking Tarpeia, Basilica Aemilia, frieze detail, $1^{\text {st }}$ century A.D. 


\section{Acknowledgments}

The author would like express sincere gratitude to the faculty and staff at Rollins College and the Cornell fine Arts Museum for allowing the rare Sabine sarcophagus to be used in academic research and incorporating the sepulchral relief in curricula for the enriched study of the humanities.

\section{Special Thanks to}

Dr. Ena Heller, Director of the Cornell Fine Arts Museum at Rollins College.

Dr. Robert Vander Poppen, Assistant Professor of Classical Art and Archaeology and the Archaeology Program Coordinator at Rollins College.

Dr. Amy Galpin, Curator of the Cornell Fine Arts Museum. Dr. Michele White, Florida Archaeological Survey, supporting researcher FAS Archaeometry Project.

Ethan White, Trinity History Honors, for conservator preservation work with the Sabine sarcophagus.

Donato Attanasio, of The Institute of the Structure of Matter of the Italian National Research Council, Consiglio Nazionale delle Ricerche - Istituto di Struttura della Materia, Rome, Italy.

Julia Cox, Research Coordinator, Department of Geology, University of Georgia.

Ashmolean Museum of Art and Archaeology, University of Oxford.

Istanbul Archaeological Museum, Turkey.

Museum of Archaeology and Anthropology, University of Cambridge.

Museo Chiaromonti, Citta del Vaticano.

\section{References}

[1] Moens, L., Roos, P., De Paepe, P., and Scheurleer, R. L., 1992, Provenance determination of white marble sculptures from the Allard Pierson Museum in Amsterdam, based on chemical, microscopic and isotopic criteria, in Ancient stones: Quarrying, trade and provenance (eds. M. Waelkens, N. Herz and L. Moens), 269-76, Acta Archaeologica Lovaniensia Monographiae, Leuven University Press, Leuven.

[2] White, F. A., 2014, Marble provenance investigation of the Roman Sabine sarcophagus, Open Journal of Archaeometry, 2(1):5232.

[3] Pensabene, P. Martinez, M. P., Turi, B., and Valeri, C., 2002, Historic-artistic and archaeometric studies of the sculptures of the Museum of Ostia. Per. Mineral.71, Special Issue: Archaeometry and Cultural Heritage, pp.173-187.

[4] Stefanidou-Tiveriou, T., 2009, Thasian marble: a connection between Thassos and Thessaloniki, in ASMOSIA VII, Proceedings of the Seventh International Conference on the Study of Marble and Other Stones in Antiquity, Thassos 15-20 September 2003 (ed. Y. Maniatis), Bulletin Correspondance Hellénique suppl. 51.

[5] Kastelic, J., 1999, The Alcestis Sarcophagus and the Orestes Sarcophagus in the Vatican and Reliefs in Sempeter, Arheoloski vestnik, pp. 259-286.
[6] Cumont, F., 1942, Recherches sur le symbolisme funeraire des Romains.

[7] Kastelic, J., 1998, Simbolika Šempeter: J. Kastelic, Simbolika mitov na rimskih nagrobnih spomenikih: Šempeter v Savinjski dolini.

[8] Holden, A., 2008, The Abduction of the Sabine Women in Context: The Iconography on Late Antique Contorniate Medallions, American Journal of Archaeology, Vol. 112, No. 1, pp. 121-142.

[9] Nock, A. D., 1946, Sarcophagi and Symbolism, Amer. Jour. Arch. 50.

[10] Koch, G., Sichtermann, H., 1982, Römische Sarkophage, 581-617.

[11] Sichtermann, H., Koch, G., 1975, Griechische Mythen: H. Sichtermann, G. Koch, Griechische Mythen auf römischen Sarkophagen. Unter Verwendung neuer Aufnahmen von G. Singer, Bilderhefte des Deutschen Archäologischen Instituts Rom, 5-6.

[12] Sichtermann, H., Koch, G., 1977, Greichische Mythen, 20-21 (8. Alkestis, G. Koch), pl. 16; 17(2); 18; M. J. Vermaseren, Corpus cultus Cybelae Attidisque (CCCA) III, Italia - Latium, EPRO 50, Leiden 1977, p. 134-135.

[13] Matz, F., 1958, Ein romische Meisterwerk. Der Jahreszeiten sarkophag Badminton, New York, JdI Erg. 19.

[14] McCann, A., 1978, Roman Sarcophagi in The Metropolitan Museum of Art, New York.

[15] Baratte, F., and Metzger, C., 1985, Musee du Louvre. Catalogue des sarcophagese $n$ pierre d'epoquesr omaine et paleochretienne, Paris.

[16] Bartman, E., 1992, Carving the Badminton Sarcophagus: Metropolitan Museum Journal, v. 28.

[17] Attanasio D., Bruno M., Yavuz A.B., 2009, Quarries in the region of Aphrodisias: the black and white marbles of Göktepe (Muğla, Turkey), JRA, 22, 312-348.

[18] Attanasio, D., Brilli, M., and Ogle, N., 2006, The isotope signature of Classical marbles, L'Erma di Bretschneider, Rome.

[19] Attanasio, D., Conti, L., Platania, R., and Turi, B., 2002, Refinement of the Classification Rule for an update of the EPR petrographic database, in Interdisciplinary studies on ancient stone-ASMOSIA VI, Proceedings of the Sixth International Conference of the Association for the Study of Marble and Other Stones in Antiquity, Venice (ed. L. Lazarini), 149-55, Bottega d'Erasmo Aldo Ausilio Editore, Padova.

[20] Herz, N., 1985, Isotopic analysis of marble, in Archaeological geology (eds. G. J. Rapp and J. A. Gifford), 331-51, Yale University Press, New Haven, CT.

[21] Herz, N., 1987, Carbon and oxygen isotopic ratios: A database for classical Greek and Roman marble, Archaeometry, 29(1), $35-43$. 
[22] Herz, N., 1988, The oxygen and carbon isotopic database for classical marble, in Classical marble: geochemistry, technology, trade (eds. N. Herz and M. Wealkens), 305-14, NATO ASI Series E: Applied Sciences, Kluwer Academic, Boston.

[23] Lazzarini, L., et al., 1988, "Determination of the Provenance of Marbles Used in Some Ancient Monuments in Rome," in Classical Marble: Geochemistry Technology, Trade, Norman Herz and Marc Waelkens, eds. (Dordrecht) pp. 399-409.

[24] Maniatis, Y., Mandi, V., and Nikolaou, A., 1988, Provenance investigation of marbles from Delphi with ESR spectroscopy, in Classical marble: geochemistry, technology, trade (eds. N. Herz and M. Wealkens), 443-52, NATO ASI Series, E: Applied Sciences, Kluwer Academic, Boston.

[25] Maniatis, Y., and Mandi, V., 1992, Electron paramagnetic resonance signals and effects in marble induced by working, Journal of Applied Physics, 71(10), 4859-67.

[26] Maniatis, Y., 2004, Scientific techniques and methodologies for the provenance of white marbles, in Proceedings of the International School of Physics 'Enrico Fermi': 'Physics Methods in Archaeometry'(eds. M. Martini, M. Milazzo and M. Piacentini), 179-202, Societa Italiana di Fisica, Ios Press, Amsterdam.

[27] Maniatis, Y., Tambakopoulos, D., and Dotsika, E., 2010, Marble provenance investigation of Roman sarcophagi from Thessaloniki, Archaeometry 52, 1 (2010) 45-58.

[28] Ashby, T., 1907, Papers at the British School in Rome, Vol. IV, No.i, London, UK.

[29] Vacca, F., 1594, Memorie di varie antichità trovate in diversi luogia della Città di Roma. Rome, Italy.

[30] Michaelis, A., 1891, Roman Mitt., p.57.

[31] Cecconi, G. F., 1725, Roma sacra, e moderna già descritta dal Pancirolo ed accresciuta da Francesco Posterla.

[32] Gaddi, G., 1736, Roma nobilitata nelle sue fabbriche, Rome, Italy, p.149.
[33] Nardini, F., 1666, Roma Antica.

[34] Koeppel, G. M., 1986, Reliefs: G. M. Koeppel, Die historischen Reliefs der römischen Kaiserzeit IV: Stadtrömische Denkmäler unbekannter Bauzugehörigkeit aus hadrianischer bis konstantinischer Zeit, Bonner Jb. 186, 1-90.

[35] Kranz, P., 1984, Jahreszeiten-Sarkophage, ASR, V, pt. 4, Berlin.

[36] Barbin, V., Ramseyer, K., Decrouez, D., Burns, S. V., Chamay, J. and Maier, J. L., 1992, Cathodoluminescence of white marble: An over view, Archaeometry, 34, 175-83.

[37] Gorgoni, C., Lazzarini, L., Pallante, P., and Turi, B., 2002, An updated and detailed mineropetrographic and C-O stable isotopic reference database for the main Mediterranean marbles used in antiquity, in ASMOSIA 5: Interdisciplinary studies on ancient stone, Proceedings of the Fifth International Conference of the Association for the Study of Marble and Other Stones in Antiquity (eds. J. Herrmann, N. Herz, and R. Newman), 115-31, Museum of Fine Arts, Boston, Archetype Publications, London.

[38] Pensabene, P. Martinez, M. P., Turi, B., and Valeri, C., 2002, Historic-artistic and archaeometric studies of the sculptures of the Museum of Ostia. Per. Mineral.71, Special Issue: Archaeometry and Cultural Heritage, pp.173-187.

[39] Perugini, D., Moroni, B., and Poli, G., 2002, Characterisation of marble texture by image and fractal analysis, in Interdisciplinary studies on ancient stone, Proceedings of ASMOSIA VI Conference, Venice, 15-18 June 2000 (ed. L. Lazarini), 241-6, Laboratorio di Analisi dei Materiali, Antichi Bottega D'Erasmo, Padova.

[40] Polikreti, K., and Maniatis, Y., 2002, A new methodology for marble provenance investigation based on EPR spectroscopy, Archaeometry, 44(1), 1-21.

[41] Tambakopoulos, D., 2007, Use of combined methods for the determination of the origin of marble artifacts, M.Sc. thesis, National Technical University of Athens. 